\title{
The Tractatus Theologico-Politicus and the Dutch: Spinoza's Intervention in the Political-Religious Controversies of the Dutch Republic
}

\author{
Henri Krop
}

check for

updates

Citation: Krop, H. The Tractatus

Theologico-Politicus and the Dutch:

Spinoza's Intervention in the

Political-Religious Controversies of the Dutch Republic. Philosophies 2021,

6, 23. https://doi.org/10.3390/

philosophies6010023

Received: 9 February 2021

Accepted: 9 March 2021

Published: 15 March 2021

Publisher's Note: MDPI stays neutral with regard to jurisdictional claims in published maps and institutional affiliations.

Copyright: (C) 2021 by the author Licensee MDPI, Basel, Switzerland. This article is an open access article distributed under the terms and conditions of the Creative Commons Attribution (CC BY) license (https:/ / creativecommons.org/licenses/by/ $4.0 /)$.
Erasmus School of Philosophy, Erasmus University Rotterdam, 3000 DR Rotterdam, The Netherlands; krop@esphil.eur.nl

\begin{abstract}
This paper outlines the Dutch background of the Tractatus theologico-politicus (TTP) and aims to contribute to a deeper understanding of the Theological-Political Treatise. It reads Spinoza's first main work published anonymously as an intervention in the many political-religious controversies, which began in 1579 and ravaged the Dutch Republic during the first century of its history. The three main topics of these controversies are also the focus of the TTP: I. the freedom to philosophize; II. the relation between Church and State, and III. the nature of public religion, which is defined by a minimal creed. These topics were familiar to the contemporary Dutch reader. The TTP appears to give a theoretical account of what theological-political practice was in the days of Spinoza.
\end{abstract}

Keywords: Spinoza; theological-political treatise; liberty to philosophize

\section{Introduction}

In Spinoza en zijn kring (Spinoza and his circle), the nineteenth-century biographer of Spinoza, K.O. Meinsma, observed that 1656, the year of the herem, created a fault line in the life of the philosopher [1] (p. 90). After that year, he stated, Spinoza became part of Dutch history and shared in the political and intellectual fortunes of the Dutch Republic. In 1947, the Dutch historian Pieter Geyl concluded that the TTP was merely "a piece of propaganda upholding the view of the States [Republican] Party" [2] (p. 40). Although the last observation might seem exaggerated, if only because all contemporary "Republican" commentators, who supported the party of the States of Holland were unanimous in their condemnation [3] (pp. 147-175), ${ }^{1}$ it is obvious that Spinoza had concrete political aims in mind when writing the Tractatus theologico-politicus. In letter 30, he wrote to Oldenburg that he interrupted his work on the Ethics to put on paper "his opinion on Scripture". His motives were, as he states: "the prejudices of the theologians", which hindered "the more prudent" to understand his ideas; the accusation of atheism by ordinary people and his worry about "the freedom of philosophizing", which in the Dutch Republic "the preachers suppress as much as they can with their excessive authority and aggressiveness" [4] (pp. 14-15). ${ }^{2}$ In the preface of the TTP, Spinoza maintains that the state he lives in is an ideal state: "since, then, we happen to have that rare good fortune - that we live in a Republic in which everyone is granted complete freedom of judgment and is permitted to worship God according to his mentality, and in which nothing is thought to be dearer or sweeter than freedom." However, the clergy, driven by their lust for power, threatens the peaceful

1 Related critiques include Epistola ad amicum, continens censuram Libri cui titulus Tractatus theologico-politicus written by Coccejus's disciple Johannes Melchior, who was connected to Utrecht Cartesian circles. In 1673, a second refutation was published, the Vindiciae miraculorum, by the prominent Arminian minister Jacob Batelier. The third refutation is Adversus anonymum theologico-politicum liber singularis by the Utrecht professor of philosophy Regnerus van Mansvelt. The fourth refutation was written in Dutch by Willem Blyenbergh, a Dordrecht corn trader and correspondent of Spinoza. The fifth refutation was written by Johannes Bredenburg, a Collegiant. The last refutation was Arcana Atheism Revelata, written by the Amsterdam Socinian, Frans Kuyper.

2 This fragment of Spinoza's letter is not included in the Opera Posthuma, but preserved in Oldenburg's correspondence to Boyle. 
existence of the Republic [5] (p. $\left(^{*}\right) 3 v$ ); [4] (p. 69). According to the German historian Schilling, the anticlericalism of the States Party, which Spinoza apparently shared, originated in the party strife during the so-called "Regime of True Freedom" [6] (pp. 656-657).

The front page of the TTP refers to Dutch political-religious controversies as well. The phrase "libertas philosophandi" was frequently used in the early years of Cartesianism, when the new philosophy successfully struggled to become admitted to the Dutch universities by appeal to this right, but Spinoza links this "professional freedom" to the more traditional discourse on toleration, which the Union of Utrecht (1579) codified and the idea of Batavian freedom cherished by all factions on the Dutch Republic. The phrase "Theological-Political" in the main title refers to the discourse in the Reformed states, which called the state the "Lieutenant of God" and the "Patron of the Church".

Acknowledging the Dutch background of the TTP will contribute to a deeper understanding of the Theological-Political Treatise. By reading Spinoza's first main work as an intervention in the many political-religious controversies that ravaged the Dutch Republic from its inception in 1579 to the end of "First Era without Stadholder" in 1672, known as "The Year of Disaster", which saw Johan de Witt, Grand Pensionary of Holland, executed by the mob and William III reinstated as a new Stadholder, we may also be able to assess the extent to which the TTP transcends ordinary polemics. During this century, the Orangists, supporters of the Stadholder, a position traditionally held by the Prince of Orange, fought with the Republicans. At several times, this fighting brought the Republic to the brink of civil war. In 1618/9, for example, the Stadholder Maurits of Orange as Commander in Chief of the army of the States General-a body of representatives of all seven princes of the Union-disarmed the troops of the province of Holland and had his Grand Pensionary, Johan van Oldenbarneveld, executed for high treason. Spinoza refers to this shameful event at the end of chapter 20 of the TTP [5] (pp. 331-332); [4] (pp. 350-352). It should be noted that Spinoza here also denounced the religious politics of the States of Holland at that time. All these controversies were caused by the indeterminate nature of the Dutch Republic, which in fact was no state at all. It was a conglomerate of competing and collaborating territories based on the Union of Utrecht (1579), a treaty signed by seven provinces in order to be able to wage war against their legal sovereign, the king of Spain.

In his introduction to the Dutch version of the TTP, Fokke Akkerman observes that parts of "its biblical criticism and political theory were already widely current in Spinoza's age" [7] (p. 23). Along this line, the present paper argues that the TTP was deeply rooted in existing political-religious controversies. In order to substantiate this claim, I discuss the following interrelated topics, which Spinoza focused on in the TTP and which at the same time were at the core of Dutch debate: I. the freedom to philosophize; II. the relation between Church and State mainly dealt with in chapter 19; and III. the confession of "universal or catholic religion", that is, the confession of the ideal public Church.

It may well be that Spinoza, as Curley nicely says, "did not always write what he thought and did not always think what he wrote" [4] (p. 54). The rhetorical nature of Spinoza's praise of the Republic in the Preface and of Amsterdam in chapter 20 is apparent. However, we should avoid as much as possible reading the TTP "between the lines" because Spinoza "did not say anything", which "a careful reader could get from the work". I hope to argue that the TTP asks for a careful reform and not for a radical "regime-change" of the Republic.

\section{The Freedom to Philosophize}

The introduction of Cartesianism at the Dutch universities caused acrimonious debates in which the States of Holland had to intervene. In 1656, they ordered the theologians and the philosophers not to interfere with each other's business and not to abuse the libertas philosopandi by discussing theological issues [8] (pp. 273-276); [9] (pp. 70-71). The regulations of many Dutch universities prescribed the teaching of Aristotle's works. Aristotelian notions such as substantial form and final cause were generally seen as basic to theological education [10]; [11] (pp. 181-182). Moreover, Cartesianism caused a reversal in the debate 
on Biblical hermeneutics, as we can see in Meyer's Philosophia S. Scripturae interpres (1666), because this philosophy promised a clear and final interpretation of Scripture that humanist philology was unable to provide [12].

Already early in the 17th century, the teaching of Ramism-an alternative to Aristotelianism developed by Petrus Ramus (Pierre de La Ramée, 1515-1572)—was defended by an appeal to the freedom to philosophize [13] (pp. 38-90). Hence, the existence of different philosophical systems and the obvious fact that in the Church and at the University a diversity of opinions and doctrines exist led the Utrecht divine Gisbertus Voetius (Gijsbert Voet, 1589-1676) to accept the necessity of freedom to philosophize. Voetius-infamous among philosophers for his quarrel with Descartes and mentioned as such by Spinoza in letter 43-dominated the Reformed Church for almost a century and gave his name to one of its main factions, the "Voetians". Many Voetians called for a purification of public life, a "Further Reformation", and invited the Christian magistrate to suppress "unchristian" behavior, such as drinking, gambling, and disregard of the Sabbath. In his argument for the freedom to philosophize, Voetius stated that dissent among Christians is unavoidable, even among "the orthodox", because the visible Church on earth is not the same as the invisible or mystical Church in heaven, where religion is directly taught by God and unanimity reigns by necessity [14] (p. 11) and [15]..$^{3}$ The visible Church and "orthodoxy" are of a basically human nature. Given the diversity of opinions, Voetius underlined the need for moderation and tolerance. He called them the "positive means to preserve the regime of the Church" [16].

In addition to moderation and tolerance, Voetius pleaded for liberty. In the Reformed Churches there should be a liberty, which is the golden mean between Roman Catholic intolerance and Islamic servitude that repress all discussion about religion on the one hand, and the immoderate license of libertines and Arminians, on the other [16] (pp. 683-684). ${ }^{5}$ Hence, tempered freedom prevails in the Reformed Churches [16] (p. 679). Voetius differentiates between four kinds of freedom: 1 . liberty of conscience; 2 . liberty of speech which gives no offence; 3 . academic or professional liberty [16] (p. 686); ${ }^{6}$ and 4 . theological freedom in the Church, which is limited by the fundamental tenets of the confession [16] (p. 698).

According to Voetius, academic freedom is necessary in theology because theologians, although they are orthodox, will never solve hermeneutical problems in the same manner due to the weakness of the human intellect and therefore there should be liberty to criticize and correct each other [16] (p. 680). Through the battle of opinions mankind will be able to oppose error and heterodoxy. Voetius also granted philosophers a limited, academic freedom, restricted by the other disciplines. Mundane philosophy should not intrude into the field of "sacred philosophy", which rests upon Biblical authority (and as such is part of theology) [16] (p. 687) and undermine orthodox religion by arguing, for example, that the rational soul is a mode of the body, or that the essence of man is thought alone and does not include the body (both of which will be part of resurrected man). Heretics use such pseudo-philosophy to substantiate their errors [16] (p. 687). ${ }^{7}$ If the philosophers transgress the limits of their discipline, the liberty of philosophy degenerates into license. Voetius mentions two contemporary philosophers who did so. The first is Hobbes, who in De cive dared "to discuss justification, free will and the reception of Christ in the Lord's Supper, as a philosopher" [16] (p. 687). The second is Spinoza who "as philosopher took the licence to theologize and deals with scriptural theology according to Cartesian method only" [16]

\footnotetext{
3 The following section on Voetius is also to be found in a slightly expanded form in [15], esp. p. 194.

4 The title of Politicx ecclesiasticx pars III, lib. 2, tract. 2, c. 2, Johannes van Waesberge: Amsterdam, 1676.

5 "Pugnant cum libertate prophetandi, 1. In defectu primo servitus \& tyrannis Muhammedica, per quam de religione non licet disquirere. [cf. Spinoza's observations on "the religion of the Turcs" in the preface of the TTP, 7] Deinde servitus inquisitionis Papalis. II. In excessu, Socinianorum, Remonstrantium, Vorstii, Acontii postulata libertas prophetandi, revera intolerabilis licentia: quippe qui eam ad fundamentalia, dogmata de Dei attributis, trinitate, persona \& officiis Christi \&c. extendunt."

6 Voetius uses here the phraes libertas scholastica or libertas in philosophicis.

"plura istiusmodi pseudo-philosophemata ab Epicureis, Socinianis aliisque ad haeresiarum suarum stabilimentem facile assumi possent."
} 
(p. 682). ${ }^{8}$ Therefore, although Voetius remained a staunch Aristotelian throughout his life and rejected Cartesianism passionately, he acknowledged a clearly circumscribed liberty to philosophize.

The first to bring up the notion of the freedom of philosophy to defend the teaching of Cartesianism was Adriaan Heereboord. In 1647, he began his public lectures with an address De libertate philosophandi. In a disputation of an uncertain date on the same topic, he had his student argue that although Aristotle was the first to develop a philosophy that provided causal knowledge of phenomena, it is not the norm of truth [17] (p. 330). Such a norm is based on empirical perception and reason and not the authority of a master. He therefore abhorred the slavish mind of an Averroes, who merely commented on the books of Aristotle, and the monkish scholastics. Moreover, he argues, Aristotelian philosophy, as all philosophy, is often ambiguous, poorly written, controversial, and dubious. The cause is the weakness of the human intellect, which lacks the capacity to penetrate the secrets of nature. After the Reformation, which ended a millennium of pagan and heterodox scholars and of Aristotelian philosophy, the Christian philosopher is at liberty to judge for himself in philosophical matters, certainly if by being born in The Netherlands he breathes "the free Batavian air" [17] (p. 9). ${ }^{9}$ All philosophers should be free to judge and dispute all things unhindered by any human authority or prejudice, whether they are Aristotelians, Ramists, or Copernicans. Bacon and Descartes are Heerebord's heroes because they daringly restored the ancient liberty of philosophy. He greeted Descartes as the "greatest of all philosophers, defender of Truth and the Liberty in philosophizing" [17] (p. 13). ${ }^{10}$

Seven years later, after Heereboord's Cartesian disputation, Henry Born, the last Aristotelian professor at Leiden University, stated that a philosopher should not tie himself down to the doctrine of a particular school, but should instead obey the rule of one's own reason and experience as the only sources of truth [18] (pp. 7, 9). Human weakness implies that truth is dispersed among all philosophical schools. Moreover, human doctrines must be judged freely in the light of the laws of Nature, which are established by the Creator himself. Born's argument echoes a phrase popular at that time: Plato is my friend, Aristotle is my friend, but Truth is a better friend. By 1650, both Heereboord and Born identified liberty in philosophy with eclecticism and with a teaching of philosophy that integrated ancient and current sources.

However, in 1666, four years before the publication of the TTP, the Cartesian Johannes de Raey rejected this eclecticism, since "having more masters in philosophy than one only enlarges our prison" [19] (p. 436). De Raey identified the freedom to philosophize with the freedom to use our reason without limits and to contemplate truth. This freedom consists of the liberty to know, to judge, and to will, and requires that the mind functions free from the body and the senses, a need both Plato and Descartes had acknowledged. This implies that, if scholarly activity is inevitably related to the senses as in the arts and in daily life, such liberty of judgment is unattainable and we have to rely on tradition and authority. This applies to the Bible as well, in that we use our sight and hearing capacity to read Scripture or listen to it being preached in the Church. Hence, according to De Raey, in practical philosophy and in the higher faculties of theology, jurisprudence, and medicine, there will be no liberty of philosophy. Moreover, it will never be possible to integrate theology, law, medicine, and politics into philosophy and, according to De Raey a philosopher should only be free to judge about the things that are his own, that is say, all things accessible through human reason.

In the context of Dutch academic education, the "freedom to philosophize" at the time of Spinoza meant the freedom of the scholar to do his job, i.e., to teach physics or

8 "Huc referri debet tract. Theologico-politicus, de libertate philosophandi nuper ab ex-Judeo quo, sed naturali psychico theologo ac philosopho, ubi prætextu libertatis philosophandi secundum methodum Cartesii (cui unicè addictum se ostendit) licentiam quærit \& sumit contra veritatem Christianæ religionis, \& theologiam scripturariam theologizandi".

9 Epistola ad curatores: "nulli negandum in disputando, ingenii et judicii libertatem, sub libero ac Batavo aere natus".

10 Epistola ad curatores: "salve philosophorum maxime, veritatis, philosophiae, libertatis in philosophando, stator, assertor, vindex." 
mathematics without interference of the "higher" disciplines or external authorities and to be able to criticize another scholar [20] (pp. 6-7). Its defense was generally accepted and Spinoza also endorsed this policy. In letter 13, for example, he refers to a scholarly dispute between Descartes and Boyle, in which Boyle criticized Descartes "without any harm to the Nobility" of both. Such procedure in science is in accordance with the liberty to philosophize as conceded to every scholar [21] (p. 210). However, the liberty of philosophy should not endanger political stability by intruding into domains of life that are not ruled by reason alone. This outcome of the Cartesian controversies, as we find in De Raey, Spinoza also endorsed. As we read in letter 48, Spinoza reacted with deep distrust to the offer of a chair of philosophy at Heidelberg University because "the liberty to philosophize" is - and should be-restricted by the requirements of public religion. Spinoza believed that if the philosopher interfered with public religion, it might cause social conflict and turmoil. [4] (p. 397). Spinoza also accepted censorship and willingly, as he stated, submitted the TTP to the judgment of the supreme "Powers of my Country" and if they-apparently to Spinoza's surprise-will judge it to be incompatible with public welfare, he wanted the book to be unwritten [4] (pp. 353-354). However, unlike for example De Raey, according to Spinoza, philosophy had no rivals in the field of scholarship because theology-as it is based on the imagination-provides for a totally different kind of knowledge and is in fact no science at all. Therefore, he writes in chapter 15: "I've shown how Philosophy is to be separated from Theology, what each principally consists in, and that neither should be the handmaid of the other, but that each has charge of its own domain without any conflict with the other" [5] (pp. 250-251); [4] (p. 281). A separation of both disciplines is also aimed at by the States of Holland in 1656, but in the TTP it is not the result of a decree by a political authority, rather, it is the outcome of philosophical argument.

In the TTP, the freedom to philosophize is related to the political freedom of speech and to the religious freedom of all to worship God in their own way. The combination of these forms of liberty seems to be new in the TTP, but as we saw before, Spinoza himself believed that the last two forms of freedom were taken for granted in the Dutch Republic, and neither religious freedom nor civic liberty as we find defended in chapter 20 of the TTP aroused any indignation or even comment among its early critics, although they were always eager to denounce the philosopher in public. Only Van Mansvelt dealt with this topic. The Utrecht professor argued that our deeds are never wholly separated from our opinions and rejected Spinoza's observation that "so long as one behaves according to the decrees of the sovereign authorities, one cannot act contrary to the decree and dictates of one's own reason" [22] (p. 354). ${ }^{11}$ This implied the destruction of human freedom, Van Mansvelt argued, because the decrees of authorities will often be unjust and false and, sometimes they will be in conflict with the judgments of citizens. It is therefore impossible that "we wholly transfer our right to live according to our own judgments to the sovereign" [22] (p. 293). ${ }^{12}$ On the other hand, "reasons of state" will often require the curtailment of citizens' rights and liberties, and this is the case even in Amsterdam, where the authorities reduced the religious freedom of the Roman Catholics and the sects [22] (p. 362). According to Van Mansvelt, Spinoza's praise for the city of Amsterdam does not describe an actual situation, but refers to a Utopia. These comments of Van Mansvelt show that Spinoza and his Dutch contemporaries shared the language of liberty but his philosophical underpinning is different. According to the TTP, however, liberty is not a concession to human weakness or an instrument for preserving political stability, but the "freedom to philosophize" is essential to science scholarship and to peace and piety. As Yoram Stein also shows in this issue, Spinoza's TTP transformed traditional tolerance from a defect, which should be avoided where possible, into a virtue, which contributed to social cohesion.

Cf. TTP, 20, Curley, p. 347.

2 Cf. TTP 17. 


\section{The Relation between Church and State}

The combination of the theological and the political in one word, as Spinoza used it in the title of this "second masterpiece", is anything but new in the Reformed tradition. In 1620 , for example, a theological-political academic discourse was held at Giessen University "on the hard question whether we may defend with arms the exercise of our religion against a prince who is trying to prevent it by force" [23-25]. In 1662, eight years before the TTP, a Dutch book was published with the Latin title Theologico-politica dissertatio. It argued on theological and political grounds against religious freedom for Roman Catholics [26]. Theo Verbeek concludes that "theological-political" denotes books with political arguments based on Scripture, as did "many 16th and 17th century treatises on politics" [20] (p. 8).

The Reformation of the 16th century secularized religion and the Church and made conscience the supreme authority of individual faith. At the same time, by eliminating the Pope, the Magistrate came to be seen as the unrivalled viceroy of God on earth and the prince the head of the Church. In the Union of Utrecht of 1579, article 13 states that "every individual may stay in his religion and because of his religion nobody will be submitted to investigation and inquiry". ${ }^{13}$ In the seventeenth century, the freedom of conscience and of thought accorded by the Union of Utrecht to the inhabitants of the Seven Provinces was generally acclaimed, and foreign commentators regarded this liberty of thought as a basic feature of the federation. William Temple, for example, wrote in 1673: "It is hardly to be imagined how all violence and sharpness, which accompanies the differences of Religion in other Countreys, seems to be appeased or softened here, by the general freedom which all men enjoy, either by allowance or connivence. No man can here complain of pressure in his Conscience" [27] (p. 181). Freedom was seen as a basic asset of a viable society, not only by radical political thinkers such as Spinoza and the De La Court brothers but also by the "orthodox". However, the very same article 13 of the Union of Utrecht made it obvious that the freedom of thought enjoyed by the inhabitants of the Dutch Republic was in no way absolute, because it coincided with a Public Religion, established by the secular authorities in view of the peace and well-being of the people. ${ }^{14}$ The United Provinces, just like every other pre-modern European state, adopted a Church, which dominated moral, social, and political life. No separation of Church and State existed. The Grote Vergadering of 1651 confirmed the engagement of the Dutch State for the case of Calvinism. ${ }^{15}$ This General Assembly issued a Naedere Unie (the Further Union), which underlined the political importance of the Synod of Dordt (1618-1619). This Synod was both an ecclesiastical assembly of the Dutch Reformed Church and a political event, for the States General of the Union also invited the other reformed powers and Churches. The delegates had to settle the theological-political controversies, which during the Twelve Years' Truce had brought the Dutch Republic to the verge of civil war. Moreover, in the Dutch Republic the town magistrate appointed the ministers of its churches and paid their salaries and the Provinces took care of their education at the universities-the main objective of the establishment of Leiden University after the revolt [10] (p. 18). The universities were part of the religious-political system. Many university charters contained a stipulation which said that the professors had to sign the confessional writings of the Church [10] (pp. 130 ${ }^{16}$, 168-169). In the 1980s, the German historian Heinz Schilling introduced the notion of a Confessional State in order to indicate the intricate relationships in the pre-modern era between state, dominant religion, and other more or less tolerated religions in its territories.

3 In the original: "schijn religie vrij sal moegen blijven ende dat men nyemant ter cause van de religie sal moegen achterhaelen ofte ondersoucken".

14 In the original: "als si tot rust ende welvaert van de provincien, steden ende particulier leden van dyen ende conservatie van een ygelick, gheestelick ende weerlick, sijn goet ende gerechtigcheyt doennelick vynden sullen."

15 For example, in N. Wiltens (ed.) Kerkelyk plakaaat-boek, Slethus: Den Haag, 1722, I, p. 6: "The States of the Provinces have declared and hereby will declare that they will maintain the true Christian reformed Religion as at the moment it is preached and taught in the Churches in these countries and furthermore in the year 1619 at Dordrecht is confirmed by the National Synod" (my translation). According to the Supplement volume, the assembling States promised to repress serious sins such as the profanation of the "Sabbath of the Lord" and in "Socinian Writings".

16 Franeker: "professores in religione cujus summa Catechesi Heidelbergensis Belgicaque Ecclesiarum et confessione Belgicae Ecclesiae comprehensa est, consentiant". 
According to him, the Dutch Republic was no exception to the general European rule, and no political-religious party in the Republic seriously questioned the need for a religious footing of state and society [28].

All leading theologians in the confessional state accepted the state's power in religious and ecclesiastical matters. Voetius, for example, fully acknowledged the authority of the secular authorities to interfere in church business, since the Magistrate possesses his power by divine law [29] (pp. 133-134). Reformed theologians and their adversaries tended to identify their view as a golden mean. On the one hand, Roman Catholicism saw all authority in society conferred on the Pope by God, who transferred his power to the Magistrate. Erastianism, on the other hand, argued that God had primarily conferred all power to the Magistrate, which delegated a part of its power to the ministers of the Church. However, within the Dutch Reformed Church the Arminian theologian Wttenbogaert in his 1610 Tractaet van 't ampt ende authoriteyt eener hoogher christelicker overheydt, in kerckelicke saecken (Treatise of the office and authority of a higher Christian government), reprinted in 1647 , denounced a model of "collateralism", or equal authority "evenhoogheid", which distinguished between two powers of God delegated to the Magistrate and the Church. He attributed this model to his Counter-Remonstrant adversaries [30] (pp. 17-26). In 1615, the Counter-Remonstant minister Antonius Walaeus, who after the Synod of Dordt became Leiden University's primary professor of theology, reacted in Het ampt der kerckendienaren, midtsgaders de authoriteyt, ende opsicht, die een hooghe christelicke overheydt daer over toecompt insonderheyt over het Tractaet des E.I. Wtenbogaerts (The office of the Ministers of the Church and the Authority and Supervision, which the Christian government is entitled to), flatly denying that the Counter-Remonstrants adhered to such a model. He argued that the Magistrate is the guardian of the Ten Commandments and had the duty to implement these. Hence, the state chooses a public religion by the mandate it receives from God. More particularly, the state had to protect the Public Church and defend religion against the foes of Divine Truth. Walaeus, however, added that the Church had a spiritual office given to it directly by God. This observation refers back to the early days of the Reformation, when John Calvin in part 5 chapter 20 of his Institutions of the Christian Religion wrote: "it is a Jewish folly to include the kingdom of Christ under the elements of this world", thereby implying a clear-cut distinction between "earthly" civil power of the state and the spiritual kingdom of God, where there are no "courts, laws and magistrate" and every Christian enjoys complete spiritual freedom. However, Calvin also noted that God himself established the Magistrate, and so "the nature of magistracy is to be derived from the word of God" [31] (pp. 637-638).

In Protestant tradition, Philip Melanchthon had already attributed the duty to provide for religion to the State. It had the custodia or cura religionis [32]. This care included both tables of the Ten Commandments, that is to say not only those regarding inter-human relations but also those regarding the service due to God [32] (p. 229) and [33] (pp. 309312). The view that government has to enforce all Ten Commandments implies the full authority of the state with regard to public religion. During Johan de Witt's regime, some radical thinkers did indeed come to this conclusion. In 1665, for example, "Lucius Antistius Constans", a name sometimes identified as a pseudonym for Spinoza, De La Court, Meyer, or Van Velthuysen, wrote an argument "in accordance with nature and right reason", against the claim of the Church to have an intrinsic right to potestas spiritualis [34]. ${ }^{17}$ Religion is either inner or outer and public, the author observed in the first chapter. Inner religion makes man only accountable to God; for no prince knows the hearts of his fellow men nor can he cause their outer religion to correspond to their real faith. Only God possesses this power. In inner religion, an absolute liberty of conscience prevails. Public religion, however, is a social affair. Therefore, in civil society, God gave his power to determine what is just and true in religion exclusively to the Magistrate. Henceforth, the state represents God in all public affairs, including those of the Church. That is the

17 H. Blom in the preface of the 1991 reprint with a French translation, p. xi suggests that the author was a regent, who died young. 
reason why Constans called the Magistrate prodeus or prodei, "since he becomes God and is the lieutenant of God and acts in stead of Him" ([34], p. 23). Although the author adopted Hobbes's natural law concepts, by attributing the ius circa sacra to the Magistrate, he remained within the bounds of the Reformed tradition.

Voetius sought to avoid such Erastianism by adding to the sentence "the magistrate is granted authority in ecclesiastical matters by divine law" the phrase "not in itself, or as such, but as far as they pertain to this world". This left the Church an authority and office of its own [14] (p. 131). ${ }^{18}$ Hence, the power of the State with respect to public religion is limited since the Church has the authority to decide its internal and spiritual affairs by itself. The first who clearly formulated this distinction between the internal and external affairs of the Church was a Jena theologian in the first decades of the seventeenth century [34] (p. 275). Justus Lipsius introduced the concept ius in sacra and Grotius adopted the expression ius circa sacra in order to demarcate the power of the State-the ius circa sacra-and the authority of the Church-ius in sacris [35] (p. 375). However, Reformed scholars had a hard time defining the proper power of the Church. Marten Schoock for example, who became (in)famous in the history of philosophy by vehemently attacking Descartes in his Admiranda methodus (1643), defined the Magistrate with Jean Bodin as "the highest power over citizens and subjects, which is free from laws" [36] (p. 91). ${ }^{19}$ It is delegated because only God is a real magistrate. God established all earthly powers, and they take part in His power to order and rule the states of earth. Therefore, they are called His "lieutenants" (velut vicarii) [36] (p. 3). This phrase is orthodox and Calvin used it in the last chapter of his Institution [31] (p. 550). ${ }^{20}$ This delegated power explains why the prince may promulgate laws "not only with respect to civil but also with respect to sacred matters" [36] (p. 112). ${ }^{21}$ However, as Ambrosius stated, "the emperor is not above, but in the church", the Magistrate is provided with the "architectonic power" to determine what matters are sacred. In doing so, the prince is guided by the Bible. Therefore he is called "the educator of the churchs" [36] (p. 113). ${ }^{22}$ Referring to the famous chapter 13 of St. Paul's letter to the Romans, Schoock maintains that the Church and its ministers have to obey the state even if it is pagan or heretic. The only specific duty of the Church God conferred on it is to admonish and correct the state. Schoock substantiates this claim by referring to Calvin's successor Theodore de Bèze [37] (pp. 630, 643). However, in exercising this duty, the ministers have to be extremely cautious to avoid tumult. It is only with respect to doctrine that the Church may act with confidence. In the history of the Church, several examples seem to contradict this very restricted notion of ecclesiastical power, such as Ambrosius, who excommunicated the emperor Theodosius the Great because his troops massacred the inhabitants of Thessaloniki in 390 CE-a counterexample which Spinoza also discusses in the beginning of chapter 19. Schoock adopted the solution of Bodin, who observed that Ambrosius, being the bishop of Milan, was not competent to judge the morals of the emperor because he was a member of the Church of Constantinople. Moreover, this killing was not a bloodshed, but a lawful execution because these citizens committed a capital crime by killing some civil servants [38] (p. 339). We may conclude that Wttenbogaert falsely attributed the idea of a real "collateralism" of Church and State to his Counter-Remonstrant adversaries.

Article 13 of the Union of Utrecht on the one hand implied the notion of a Christian magistrate but on the other granted all citizens liberty of conscience. It created a major intellectual problem in the Confessional State, namely to account for the tolerance of "false

18 [the State] "Habere supremam et formalem potestatem in omnes subditos. 2. Habere specialiter coactivam supremam et formalem potestatem in personas, res, actiones et causas ecclesiasticas non quidem in se aut qua tale, sed sed quatenus ad hoc saeculum" and "Potestas magistratus esse immediatè à Deo et ideo independenter ab ecclesia est jure divino". "summa in cives ac subditos legibus absoluta potestas".

20 The magistrate "mandatum a Deo, Divinum authoritatem praeditos esse, ac omnino Dei personam sustinere, cujus vices quodammodo agunt".

21 "ea se non modo ad negotia sacra ac ecclesiastica quam civilia extendat".

22 "Sic erit nutricius genuinus ecclesiae, maxime si non minus ad conservandae orthodoxae religionis, quam extirpandae heterodoxae, quam gnaviter incumbuerit". 
religion", i.e., convictions at variance with public religion and its confession. If someone rejected it, Voetius observed, he deserves eternal damnation. The Church does not tolerate such an unbeliever in its midst and rightly considers him to be excluded from the Kingdom of God. Hence, the king of Great Britain did a good thing when he committed a Socinian to the flames. Apparently, this theory leaves little hope for toleration. Voetius maintained: "since by divine and natural law the state is the defender of religion, the Magistrate is in conscience bound to promote and favour it as far as in its power and take away all evils and sins that do harm to the glory of God.... and some theological errors are intolerable in a state, such as the assumption that God does not reign over human affairs and is not the judge of evil deeds, the Magistrate should prohibit the public exercise of such a false religion" [29] (p. 388 23) and [33] (pp. 314-315).

However, the practice Voetius advocated is less harsh than the theory because the clause put in italics to a certain degree made the tolerance of "false" religion possible. The authority of the Magistrate is essentially a juridical authority based on all kinds of treaties, conventions, and agreements and the use of its power required prudence. According to Voetius, a threefold practice of tolerance of "false" religion in a Confessional state developed. The Magistrate in the Dutch Republic "permitted" false religion in the case of Lutheranism. "Tolerance" occurs if the Magistrate sincerely wants to ban a false religion but is unable to do so safely. This is the attitude of the Reformed Government against Roman Catholicism, which the authorities occasionally prohibited merely due to "political reasons". Finally, "indulgence" is where the Magistrate applies the existing banning edicts with moderation. This is the case with Arminianism. However, Socinianism, Paganism, and Judaism were false religions, which in the Dutch Republic deserved no tolerance at all because they denied the basic tenets of Christianity. The same applies to Anabaptism and Arminianism if infected by Socinianism. Even a limited amount of force in destroying false religion was allowed. Individuals may be forced to emend their faith before the Magistrate, but "inquisition and tyrannical coercion of conscience" should be avoided [29] (p. 390). ${ }^{24}$. In this manner, the repression of false religion should coexist with the liberty of conscience.

Voetius's view on tolerance reflected the general practice in the Dutch Republicwith the possible exception of the Jews who were admitted to some Dutch cities [39] (pp. 437-438). The Public Church preached true religion and admonished all citizens to follow its lead. The secular authorities only intervened if they considered the foundations of the political-religious order to be at stake. Governmental bodies interfered by banning books [40] (p. 95), ${ }^{25}$ fining printers, and imprisoning authors. So, theoretical intolerance coexisted with a large but not unlimited practical tolerance.

However, new theological-political turmoil was caused by the "Further reformation", that is to say the Dutch version of Puritanism. In the 1650s, influential parts of the Public Church were dissatisfied with the continuing presence of dancing, public swearing, gambling, wearing long hair, theatrical performances, and disregard of the Sabbath. Apparently, these distressing phenomena were proof of the incompleteness of the Reformation and the unchristian nature of the Dutch society. An impediment to the Further Reformation, the Voetians argued, was the Magistrate, which refrained from using its power to repress all "ungodliness" and "false religion", although it could easily do so by closing theaters and bars.

At the time when Voetius developed his ideas on the "exercitia pietatis" in Utrecht, the leading theologian at Leiden University was Joannes Coccejus. In the Dutch Republic, his federal theology was also very popular. He and other leading theologians felt the "Further Reformation" eroded "Christian liberty". The political-theological controversy stimulated by the "Further Reformation" and conflicts caused by the introduction of Cartesianism

"non licet magistratui, Dei ministro, libertatem excercitii sive publicam permittere siquidem potestas et potentia illi adsit impedienda". 
coincided and the followers of the States Party tended to support the sympathizers of Coccejus in the Public Church and of Cartesianism in the universities and vice versa. This makes apparent that there is no intrinsic link between republicanism, Coccejan theology, and Cartesianism. Already in the nineteenth century, the Church historian J.A. Cramer concluded that external factors brought these groups together, that is the power of a common enemy, the voetian Further Reformation [41] (p. 39). ${ }^{26}$

The first who linked Cartesianism with theology was Lambertus van Velthuysen (1622-1685) [42] (p. 14) and [43]. ${ }^{27}$ From the very beginning, his focus on Christian liberty destroyed the foundations of the program of the Further Reformation. Of course gambling, drinking, and usury are evils, he argued, and every sinner has to justify his misbehavior to God, but the citizen is in no need to account for his sins to the Magistrate. Unlike Voetius, Van Velthuysen did not write a treatise devoted to state and Church relationships, but the contours of his theologico-political argument, comprising biblical interpretation, the fundamental articles of Faith, the nature of the Church, and its relation to the state, are clearly visible in the Dutch pamphlets he wrote during the 1660s. According to his Tractaet van de Afgoderye en Superstitie (Treatise on idolatry and superstition), the purest act of idolatry-unsurprisingly, considering Van Velthuysen's Protestant persuasionsis the Roman Catholic Mass, described by the Heidelberg Catechism (question 80) as an "accursed idolatry" [45] (p. 1). Yet, Van Velthuysen's aim is not to participate in confessional polemics, but to adjust the balance between the Magistrate's duty to defend true religion and the liberty of conscience. In a pamphlet of 1660, he argued that Christian magistrates are not duty-bound to ban gambling, drinking, and providing interest-bearing loans [46] (p. *4r). Although the Magistrate is obliged to promote God's honor which is injured by these vices, this is counterbalanced by the reason of state, the "general need for the state to allow evils in order to prevent still greater evils". This is the case, for instance, with the toleration of Jews and Catholics, who are needed for the economy [46] (p. 271ff). Moreover, magistrates are obliged to enforce moral discipline in three cases only: first, if the preservation of the state is in danger; second, when the "first imprints of honor and shame" are involved: moral notions so evident that nobody can willingly deny them, unless he is a blinded atheist who "purely out of spite spurns all good arguments for God's existence" [46] (p. 73); and finally, in those cases where Scripture clearly states that God has delegated the punishment of the wicked to the secular authorities. This last possibility, however, is purely hypothetical, since Christ has abrogated the Old Testament laws and the New Testament does not contain such laws [46] (p. 65).

In his polemic with the Further Reformation, Van Velthuysen secularized the Church and made it lose its sacred nature. Although the authority of Christ as an infallible teacher has in part passed on to the apostles, these, "as the Reformed well know", have not in turn found "followers or successors in this doctrinal infallibility" [47] (p. 33). This means that the Church of the Reformation is merely a union of co-religionists, which a citizen joins in freedom. The members elect the pastors, who therefore even in the Church have no greater authority than common believers, nor are church members bound by the decisions of church bodies [47] (p. 87). Like all social organizations, such as the "college of midwives" or the "college of judges", the Church is subject to the state [47] (p. 33). According to the Utrecht regent, who clearly adopted the Reformed view, this subordination is limited to the organizational aspects, i.e., outer religion. The government possesses the jus circa sacra, but does not extend itself to matters of inner faith-for conscience is outside government control. By this argument, the confession lost its divine nature and became a bylaw of the Church, which regulates its services, but which does not express the inner faith of the believers.

26 Van Asselt underlines the anti-scholastic base line in this theology and the "duplex ordo" between philosophical and theological knowledge of God. According to him, the Bible was no physical text, but a book of piety.

27 Van Bunge [9] (pp. 50-54) pays attention to the role of the theologian Christoph Wittich, who in the 1650s developed the concept of "accommodation". According to his notion originating in Calvin, the Bible spoke about physical topics in the language of the common man and contained no philosophical truths about the constitution of nature. The message of the Bible is basically of a moral nature. For this section, see [44]. 


\section{The Confession of the Public Church}

In the TTP, Spinoza establishes the nature of public religion and its confession at the end of a painstaking philological research of the Old Testament, using no less than 716 different Hebrew words [48]. All these Hebrew words appear without vocalization, which complicated a reading of the text to a reader without expert knowledge of Hebrew. Moreover, the "philosophical reader" Spinoza addresses had to comprehend the arguments, which refer to targumim and medieval Jewish commentators as well. The reader could only understand the TTP thanks to the dissemination of philological expertise as developed by humanism.

The humanist movement had transformed medieval hermeneutics into an independent "scholarly" discipline. This ars interpretandi required the study of ancient languages such as Greek and Hebrew [12] (pp. 94-98). From the 16th century onwards, all kinds of grammars, dictionaries, and concordances were written and printed for a wide community of readers, and a method to use them was developed. Humanist scholars included the study of the Bible in their activities, and theologians had to put up with the presence of such a Grammaticus (philologist), who wrote Biblical commentaries adopting the same method used in interpreting secular texts of the Ancients. The importance the Reformers attributed to the study of Hebrew is apparent in Théodore de Bèze's history of the Reformation. According to Calvin's colleague, the Reformation started with the humanist Johann Reuchlin because he made the knowledge of Hebrew available to the Church. Bèze wrote: "by divine grace the Christians regained the ability to read the 'divine secrets' once again in the languages they were written" [49] (pp. 1-4).

Spinoza's library contained no less than sixteen works that could be related to biblical philology. The most important are Buxdorf's Biblia sacra Hebraica ac selectissimis Hebræorum interpretum commentariis, Bale 1619 (folio 1); Tremulius's translation of the New Testament from Aramaic, Geneva 1569 (folio 2); Buxdorf's Hebrew grammar in two parts, 1629 (octavo 12); the Clavis Talmudica, translated by the Leiden Hebraist, l'Empereur (quarto 19); and a Dictionary of Biblical and Rabbinical Hebrew by Phillippe d'Aquin, Paris 1629 (folio 8)-all Christian Hebraists [50].

In 1627, the Leiden theologian André Rivet wrote a General Introduction to the study of the Old and New Testament [51] (p. 210). In this manual he distinguishes between two kinds of interpretation: philology, or "textual theology", which is the simple understanding of the words and sentences we find in the texts of the Bible- and the reading of these sentences as constituting the "Word of God". However, if we read the Bible texts in a literal way only, they will often seem to be contradictory or defective. Therefore, a second form of interpretation is needed to provide the Church with the necessary means to establish the content of Faith. The second form of reading the Bible presupposes its unity, and the Holy Writings to convey one message, although, according to Reformed canon, they consist of no less than 39 books in the Old Testament and 27 in the New Testament. Spinoza's friend Adriaan Koerbagh was probably the only 17th-century scholar who flatly rejected the unity of the Bible. In the entry "Bibel" of his dictionary, we read that the Bible is a collection of fictional books comparable to the legendary Reynaert the Fox or Till Eulenspiegel, a trickster figure in Medieval Dutch folklore. According to Koerbagh, an ecclesiastical assembly arbitrarily determined which books belong to the New Testament many years after the death of Jesus, but a later assembly might well change the canon if they want to. Hence, the unity of the Bible is a human construction, which "only fire and sword" maintain [52] (pp. 95-97). The unity of all those seemingly disparate biblical texts is established, as Reformed orthodoxy argued, by making Scripture itself the unique norm of interpretation, and by comparing biblical texts only to other biblical texts, but we have to read them with a "pure mind" and enlightened by the Holy Ghost. The second way to establish Faith is to read the Bible in the light of the tradition, as the Church of Rome argued [51] (p. 271)..$^{28}$

28 Cf. also Meyer's Interpres on the different keys to create a unity in the Biblical texts. 
In chapter 7 of the TTP, we find an outline of the meagre outcome of the textual approach to interpreting the Bible. Spinoza states that our knowledge of Biblical Hebrew will always remain imperfect because the Hebrew texts are ambiguous and their history is completely known to us [5] (pp. 133-135) and [4] (pp. 179-184). Therefore, we are unable to understand the Word of God. Spinoza's friend Lodewijk Meyer also viewed the results of Reformed Biblical philology with the same scepticism. In the first three chapters of his 1666 Philosophy as the Interpreter of Holy Scripture, often edited in one volume with the TTP, Meyer outlines the problems the art of interpretation encounters. They are impossible to overcome because written language is always ambiguous. Although Meyer speaks about language in general, his arguments apply particularly to Biblical Hebrew. However, the extreme diversity recorded in the historiae of the different books the Bible is a prerequisite to delineate their universal characteristics, which allows Spinoza and the philosophical reader to establish the universal doctrine of the Holy Writings [53] (pp. 46-71). ${ }^{29}$ In TTP 12 , Spinoza writes that the Bible is God's Word "only with respect to religion", that is to say with respect to its meaning and not with respect to the written texts, which are "faulty, distorted, or mutilated" and their meaning cannot be worked out "from linguistic usage or gathered solely from Scripture" [5] (pp. 217-218) and [4] (pp. 254-255). Spinoza, looking for a definition of faith, agrees with Meyer that "the rule of interpretation must be the natural light of reason which is common to all men" and therefore "the highest authority to interpret Scripture rests with each individual" [5] (p. 149) and [4] (p. 191). ${ }^{30}$ So, the force that creates unity among men is reason. Yet, this force is not "philosophical reason, but common sense". To give everyone the freedom to interpret the Bible will cause no problems because, like Euclid's geometry, the crucial parts of the Bible's teaching are expressed in ordinary language. Meyer's and Spinoza's shared concern to denounce ecclesiastical and theological authority is reflected in the TTP in the refutation of Maimonides's stance, which suggests that the Bible was written by consummate philosophers and could only be interpreted by professional philosophers. It is not his plea for reason, which made Spinoza oppose Maimonides, but his fear of a privileged class of theologians, which, as we saw, we find among other radical Dutch commentators.

In chapter 14 and 19, Spinoza, inspired by this anticlericalism, intervened in the debates on the doctrine content of the confession of the Public Church. A confession should consist of a coherent set of propositions, which define specific doctrines. They are called the articles of Faith. With phrases such as "foundations of religion", "biblical dogmas", "principles", or the fundamentals of universal Faith, Spinoza denoted the universal Faith, which may be inferred from the Bible by applying his method of interpretation, and which a believer has to accept in order to acquire salvation. The dogmas of Holy Scriptures conceived as a unity are at the same time the basic tenets of Faith [5] (praef, 6, 12, 14, pp. [A8v], 118, 218, 229) and [4] (pp. 123, 167, 255, 263).

As we have seen, determining the content of Faith or the True Religion is an important theological problem because the Magistrate should suppress opinions at variance with basic religious truths. In the second volume of the Diputationes Selectae, a manual of theology, Voetius underlined the importance of the topic and observed that it is related to basic theological issues such as the liberty to speak in the Church (libertas prophetandi), tolerance and moderation, heresy, schism, and the union of the churches [55] (p. 511). Although not all doctrine we come across in the Bible is equally relevant to "redeeming Faith and the community of the Church", it seems obvious that Faith consists of an elaborate series of truths. Faith is more than trust in a person—be it God or Christ—but obviously has a subject-matter as well. Voetius here refers to the scholastic distinction between "de quo creditur" (Who we trust) and "quod creditur" (the truths we believe in). "True faith requires the explicit knowledge of a whole sequence of truths or articles", he says [55] (p. 516). Such a sequence entails not only a small number of general principles but also

\footnotetext{
29 Touber gives a full discussion of these topics and of the relation between the TTP and the humanist philological tradition in The Netherlands.

30 I will not discuss the controversial relationship between Meyer and Spinoza. A good start is Walther [54].
} 
many logical conclusions. Judaism and Catholicism share this view, but it runs counter to Arminianism, which took the number of articles of Faith to be few. Ironically, Voetius added that the Arminians do not meet their theory of a few articles in practice [56] (pp. 715-716). Furthermore, Van Velthuysen, a member of the Public Church, rejected the Remonstrant idea that the number of basic articles of Faith are few and mainly of a moral nature: "trust in the Divine promises", obeying His precepts and reverence of Scripture [56] (p. 529). Indeed, the leading Arminian theologian Philippus van Limborgh argued that in view of Christian liberty and mutual tolerance in the Church, we should distinguish between articles "absolutely necessary with respect to salvation", which in case of unbelief make someone a heretic, and doctrines less urgent. Fortunately, the number of absolutely necessary articles are only very few and easy to find by a man who respects the Bible [57] (p. 852). Moreover, they do not include purely speculative doctrines without any relation to the exercise of piety that is morality [57] (p. 854). The bare minimum of articles was reached by Hobbes, who argued that only one article is necessary: the public declaration that "Jesus is the Christ" [58] (p. 590). However, for Hobbes, the other salutary doctrines are contained in this tenet.

Like Van Limborgh and the Arminian tradition, Spinoza relates the controversy on the number of articles of Faith to freedom: "To establish, then, how far each person has the freedom to think what he wishes with respect to faith, and whom we are bound to consider faithful, even though they think differently, we must determine what Faith and its fundamentals are" [5] (p. 230) and [4] (p. 264) and to the idea of a confession, which is beyond controversy and shared by all. However, Spinoza also links the number of the fundamental articles of Faith to his anticlericalism. He observed that in the history of Christendom the men of the Church misused the historical opportunity to extend the number of articles beyond what is necessary "to look after their interests". To that end, they "confused them with philosophy" and based them on useless speculation. So, the "Ecclesiastics" being "private men with abundant leisure" could falsely pretend to be "the supreme interpreters of Religion" [5] (p. 320) and [4] (p. 342).

\section{Conclusions}

In this paper, I argued that the Theological-Political Treatise is more than a piece of propaganda, although it shared the anticlericalism of many "Republican" commentators of the period. It is a philosophical masterpiece by its argument, but was also deeply rooted in existing political-religious controversies. It intervened in the Dutch debating culture because it addressed basis problems of the Reformed Confessional state. Notwithstanding its unique defense of philosophical, religious, and political freedom of philosophy and his anti-clerical views of the nature of Public Religion and of the relation between the State and its Church, the TTP made use of notions existing in Reformed tradition and intervened in Dutch intellectual history. The intriguing phrase "the liberty to philosophize" connected the work to the heated discussions, which the introduction of Cartesianism gave rise to. This was also the case for the more general idea of academic freedom, which even the orthodox had to concede to philosophy and philology. Spinoza included in this conception the existing notion of individual religious freedom, or freedom of conscience and also the freedom to criticize government, which he nevertheless heavily restricted. Spinoza's view of the relationship between the State and its Church did not surprise his contemporaries, I argued, because it fit well into the reformed tradition, which made the Magistrate "the Lieutenant of God" on earth. The spiritual power of the state to enforce religion was restricted, as we saw in the case of Voetius, by the liberty of conscience and of inner religion. Spinoza argued for the latter on pragmatic grounds. The third section of this paper discussed the confession of "catholic religion", which in practice is the confession of the Public Church. Both Reformed theologians and Spinoza insisted that such a confession should be the outcome of a scrupulous study of the Bible, which I argued, is to be done not only by means of philology, but also by the same common sense of every man, who is also able to grasp its truths simple as the propositions of mathematics. Spinoza's theological- 
political treatise was seen as a normal intervention in the political-theological debates of his age. However, it was his philosophy, shining through the text, which aroused the indignation of his critics and remained highly controversial during the Enlightenment period and well thereafter.

Funding: This research received no external funding.

Conflicts of Interest: The author declares no conflict of interest.

\section{References}

1. Meinsma, K.O. Spinoza en Zijn Kring: Historisch-Kritische Studiën over Hollandsche Vrijgeesten; Nijhoff: The Hague, The Netherlands, 1896; Reprint 1980, German version, 1909, French version 1986.

2. Geyl, P. Het Stadhouderschap in de Partij-Literatuur Onder De Witt; Mededeelingen der Koninklijke Nederlandsche Akademie van Wetenschappen Afd. Letterkunde 10; Noord-Hollandsche Uitgevers Maatschappij: Amsterdam, The Netherlands, 1947.

3. Krop, H.A. Spinoza, een Paradoxale Icoon van Nederland; Prometheus: Amsterdam, The Netherlands, 2014.

4. Curley, E. Collected Works of Spinoza II; Princeton University Press: Princeton, NJ, USA, 2016.

5. de Spinoza, B. Tractatus Thelogico-Politcus; Künrath [=Rieuwertz]: Hamburg, Germany; Amsterdam, The Netherlands, 1670.

6. Schilling, H. Afkeer van domineesheerschappij. In Anticlericalism in Late Medieval and Early Modern Europe; Oberman, H.A., Ed.; Brill: Leiden, The Netherlands, 1993.

7. Akkerman, F. Inleiding. In Spinoza, Theologisch-Politiek Traktaat; Wereldbibliotheek: Amsterdam, The Netherlands, 1997.

8. Resolutien der Heeren Staten van Hollandt ende West-Vriesland, Zedert den Aenvang der Bedieninge van den Heer Johan de Witt, 1653 tot 1668; Willem vande Water: Utrecht, The Netherlands, 1706.

9. van Bunge, W. From Stevin to Spinoza. An Essay on Philosophy in the 17th century Dutch Republic; Brill: Leiden, The Netherlands, 2001.

10. Dibon, P. L'enseignement Philosophique Aux Universités Néerlandaises à L'époque Pré-Cartésienne (1575-1652); Elsevier: Amsterdam, The Netherlands, 1954.

11. Verbeek, T. Tradition and Novelty. Descartes and Some Cartesians. In The Rise of Modern Philosophy: The Tension between the New and Traditional Philosophies from Machiavelli to Leibniz; Sorell, T., Ed.; Clarendon Press: Oxford, UK, 1993.

12. Krop, H.A. The Philosophia S. Scripturae Interpres between Humanist Scholarship and Cartesian Science. Lodewijk Meyer and the Emancipatory Power of Philology. In The Dutch Legacy: Radical Thinkers of the 17th Century and the Enlightenment; Lavaert, S., Schröder, W., Eds.; Brill: Leiden, The Netherlands, 2017; pp. 90-120.

13. Zank, K. Denkfreiheit. Libertas philosophandi in der deutschen Aufklärung; Meiner: Hamburg, Germany, 2012.

14. Voetius, G. Politicæ Ecclesiasticx; pars I t. 1; Johannes van Waesberge: Amsterdam, The Netherlands, 1663.

15. Krop, H.A. Reformed Orthodoxy and the Libertas philosophandi in The Netherlands. Church Hist. Relig. Cult. 2020, 100, 187-202. [CrossRef]

16. Voetius, G. Politicx Ecclesiasticæ Politicx Ecclesiasticx pars III; Johannes van Waesberge: Amsterdam, The Netherlands, 1676.

17. Heereboord, A. De libertate philosophandi and Epistola and Curatores. In Meletemata Philosophica; Motard: Leiden, The Netherlands, 1659.

18. Bornius, H. Oratio Inauguralis de Vera Philosophandi Libertate, Dicta in Splendidissimo \& Frequentissimo Auditorio Lugduni Batavorum, die 2 Novembris Anni 1653; Johan \& Daniel Elsevier: Leiden, The Netherlands, 1654.

19. de Raey, J. Libertas et servitus, universim atque enim in philosophando. In Cogitata de Interpretatione, Quibus Natura Humani Sermonis ... Cum Appendice; Wetstein: Amsterdam, The Netherlands, 1692; pp. 425-437.

20. Verbeek, T. Spinoza's Theologico-Political Treatise: Exploring 'The Will of God'; Routledge: Abingdon, UK, 2016.

21. Curley, E. Collected Works of Spinoza I; Princeton University Press: Princeton, NJ, USA, 1985.

22. van Mansveldt, R. Adversus Anonymum Theologo-Politicum Liber Singularis, in Quo Omnes \& Singulae Tractatus Theologico-Politici Dissertationes Examinantur \& Refelluntur ... Opus Posthumum; Abraham Wolfgang: Amsterdam, The Netherlands, 1674.

23. Gogreve, S. Discursus Academicus de Quaestione Illa Ardua Theologico-Politica: An Exercitium Religionis Contra Superiorem, Illud Vi Impedientem, Armis Defendi Iure Possit; Hampelius: Giessen, Germany, 1620.

24. de Monte Wolgeratensi, L. Discursus Theologico-Historico-Politicus: Continens Difficilimam \& Alias Multo Sanguine Notatam Quaestionem an Pro Religione Iustum Possit Geri Bellum; Universitäts- und Landesbibliothek Sachsen-Anhalt: Halle (Saale), Germany, 1631.

25. De Spinoza, B. Tractatus Theologico-Politicus, de Officiis Hominum Circa Jus Naturae; Scanorum: London, UK, 1685.

26. van Heenvliedt, S. Theologico-Politica Dissertatio, Ofte Discours over Dese Vrage: Of Den Pausgesinden in Dese Vereenighde Nederlanden, Niet en Behoorde Toe-Gestaen te Worden, D'openbare Exercitien van Hare Religie, in Enighe Openbare Kercken, of Capellen van Enige Steden of Ten Minsten in Enige Privato-Publijcke Plaetsen; Watermam: Utrecht, The Netherlands, 1662.

27. Temple, W. Observations upon the United Provinces of the Netherlands; Gellibrand: London, UK, 1673.

28. Schilling, H. Religion und Gesellschaft in der calvinistische Republik der Vereinigten Niederlande-Ö̈fentlichkeitskirche und Säkuralisation. In Kirche und Gesellschatlicher Wandel in Deutschen und Niederländischen Städten der Werdenden Neuzeit; Petri, F., Ed.; Köln 1980 (English version in Religion, Political culture and the Emergence of Early Modern Society); Brill: Leiden, The Netherlands, 1992; pp. 352-412.

29. Voetius, G. Politicæ Ecclesiasticx pars I t. 2; Johannes van Waesberge: Amsterdam, The Netherlands, 1666. 
30. Fukuoda, A. The Sovereign and the Prophets. Spinoza on Gortian and Hobbesian Biblical Argumentation; Brill: Leiden, The Netherlands, 2018.

31. Calvin, J. Institutio Totius Christianae Religionis; Gerard: Geneva, Switzerland, 1550.

32. Heckel, J. Cura religionis, ius in sacra, ius circa sacra. In Festschrift Ulrich Stutz; Verlag Ferdinand Enke: Stuttgart, Germany, 1938; pp. 224-298.

33. Goudriaan, Aza Reformed Orthodoxy and Philosophy, 1625-1750; Brill: Leiden, The Netherlands, 2006; pp. 309-312.

34. Constans, L.A. De Jure Ecclesiasticorum Liber Singularis; Pennatus: Alethopolis/Amsterdam, The Netherlands, 1665.

35. Grotius, H. De Imperio Summarum Potestatum Circa Sacra; Van Dam, H.J., Ed.; Brill: Leiden, The Netherlands, 2001.

36. Dissertatio Singularis de Majestate, Nunc ad Disputandum Publice Proposita; Widow Edzard Agricola: Groningen, The Netherlands, 1657.

37. Schoock, M. Liber de Bonis Vulgo Ecclesiasticis Dictis: De Officio Ministrorum Ecclesiae Erga Magistratus; Nicolai: Groningen, The Netherlands, 1651.

38. Bodin, J. De Republica Libri Sex; DuPuys: Paris, France, 1586.

39. Zwarts, J. De Joodsche Gemeenten buiten Amsterdam. In Geschiedenis der Joden in Nederland; Brugmans, H., Frank, A., Eds.; Van Holkema \& Warendorf: Amsterdam, The Netherlands, 1940; pp. 382-453.

40. van Bunge, W. Censorship of philosophy in the 17th-century Dutch Republic. In The Use of Censorship in the Enlightenment; Brill: Leiden, The Netherlands, 2009.

41. van Asselt, W.J. Amicitia Dei, een Onderzoek naar de Structuur van de Theologie van Johannes Coccejus (16013-1669); Grafische Vormgeving ADC: Ede, The Netherlands, 1987.

42. Nyden-Byllock, T. Spinoza's Radical Cartesian Mind; Continuum: York, UK, 2007.

43. Krop, H.A. Spinoza and the Calvinistic Cartesianism of Lambertus van Velthuysen. Studia Spinoza. 1999, 15, 107-132.

44. van Velthuysen, L. Tractaet van de Afgoderye en Superstitie; Dirck van Ackersdijck: Utrecht, The Netherlands, 1669.

45. Duker, A.C. Gisbertus Voetius III; Brill: Leiden, The Netherlands, 1914.

46. van Velthuysen, L. Ondersoeck of de Christelijcke Overheydt Eenigh Quaedt in Haer Gebiedt Magh Toe Laeten; Jan Effendewegh: Middelburg, The Netherlands, 1660.

47. van Velthuysen, L. Het Predick-Ampt en 't Recht der Kercke, Bepaelt Nae de Regelen van Godts Woordt, en de Gronden van Onse Reformatie; Cleas Hansz.: Amsterdam, The Netherlands, 1660.

48. Chamla, M. Indice delle forme ebraiche del Tractatus theologico-politicus. Qualche osservazione preliminare. Lexicon Philosophicum. 1996, 8-9, 25-73.

49. de Bèze, T. Histoire Écclesiastique des Eglises Réformées au Royaume de France; Jean Remy: Antwerp, Belgium, 1580.

50. Krop, H.A. Spinoza's Library: The Mathematical and Scientific Works. Intellect. Hist. Rev. 2013, 23, 25-43. [CrossRef]

51. Rivet, A. Isagoge, Seu Introductio Generalis ad Scripturam Sacram Veteris et Novi Testamenti; Commelin: Leiden, The Netherlands, 1627.

52. Koerbagh, A. Een Bloemhof van Allerley Lieflijkheyd Sonder Verdriet Geplant Door Vreederijk Waarmond; [s.n.]: Amsterdam, The Netherlands, 1668.

53. Touber, J. Spinoza and Biblical Philology in the Dutch Republic 1660-1710; Oxford University Press: Oxford, UK, 2018.

54. Walther, M. Biblische Hermeneutik und historische Erklärung: Lodewijk Meyer und Benedikt de Spinoza über Norm, Methode und Ergebnis wisschenschaftlicher Bibelauslegung. Studia Spinozana. 1996, 11, 227-285.

55. Voetius, G. De articulis et erroribus fundamentalibus. In Selectarum Dispationum Pars 2; Waesberge: Utrecht, The Netherlands, 1655; pp. 511-538.

56. van Velthuysen, L. De articulis et erroribus fundamentalibus. In Opera Omnia; Leer: Rotterdam, The Netherlands, 1680; pp. 693-825.

57. van Limborgh, P. Theologia Christiana; Lakeman: Amsterdam, The Netherlands, 1730.

58. Leviathan. In The English Works of Thomas Hobbes III; Bohn: London, UK, 1839. 